\begin{tabular}{c} 
Volume and Issues Obtainable at Center for Sustainability Research and Consultancy \\
Journal of Business and Social Review in Emerging Economies \\
ISSN: 2519-089X \& ISSN (E): 2519-0326 \\
Volume 7: Issue 4 December 2021 \\
CSRᄃ \\
Journal homepage: www.publishing.globalcsrc.org/jbsee \\
\hline
\end{tabular}

\title{
Be Muslim Buy from Muslims: Impact of Retailers Religious Orientations on Consumers Purchasing Patterns
}

Saba Amin, School of Business, Zhengzhou University, Zhengzhou, China

Muhammad Nabeel Safdar, School of Business, Zhengzhou University, Zhengzhou, China

*Qamar Ali, Lyallpur Business School, Government College University Faisalabad, Faisalabad, Pakistan

*Corresponding author's email: qamarali@gcuf.edu.pk

\begin{tabular}{l}
\hline ARTICLE DETAILS \\
\hline History \\
Revised format: Nov 2021 \\
Available Online: Dec 2021 \\
\hline Keywords \\
Buying Motives, Purchase \\
Intensions, Intrinsic \\
Religiosity, Extrinsic \\
Religiosity, Belief \\
Congruence Theory. \\
\hline
\end{tabular}

JEL Classification M19, Z12

\section{ABSTRACT}

Purpose: This study investigates the impact of retailers' religious affiliation and religiosity on consumers' purchasing patterns. The moderated mediation model of this study contemplates a) the mediating role of buying motives of consumers based on thoughts, feelings, emotions, which help them make decisions, and $b$ ) the moderating role of intrinsic and extrinsic religiosity dimensions.

Design/Methodology/Approach: Data were obtained from consumers from metropolitan cities of Pakistan. Simple Linear Regression and Pearson Correlation Coefficients were used to investigate the relationships with the help of SPSS and AMOS software. ArcMap was used to represent the selected sample size. Findings: Drawing on the belief-congruence theory, the findings of this study suggest that religious affiliation of the retailer (RAR) has a significantly positive impact on consumer purchase intentions (CPI) and that consumer buying motives (CBM) have a strong mediating role between RAR and CPI. The study also reveals that the impact of CBM on CPI is stronger in consumers with high intrinsic religiosity. However, data analysis shows that consumers' extrinsic religiosity is not a significant moderator of the relationship between consumers' buying motives and purchase intentions.

Implications/Originality/Value: The findings of this study can help retailers make better policies to attract consumers and sustain their businesses.

(C) 2021 The authors, under a Creative Commons AttributionNonCommercial 4.0

Recommended citation: Amin, S., Safdar, M. N. and Ali, Q. (2021). Be Muslim buy from Muslims: Impact of Retailers Religious Orientations on Consumers Purchasing Patterns. Journal of Business and Social Review in Emerging Economies, 7 (4), 847-861. 


\section{Introduction}

Consumers with a higher religious affiliation are more conscious about their purchasing decisions. Such consumers easily influence social values and norms (Razzaq et al., 2018). Religion is considered a part of the culture. It can have a far-reaching impact on individuals' values, propensities, and stances. It extraordinarily impacts life, thus influencing shoppers' decision-making about the particular item. Religion has been characterized as an arrangement of customs justified by myth, which assembles extraordinary forces with the end goal of accomplishing or avoiding changes of state in the human and natural world (Barrett, 2011). Consumers who are highly affiliated with religion can gather more information about the new product before purchasing it. Consumers with a high level of religious commitment show less interest in purchasing the new product; such consumers are more loyal towards the brands they are already using because they are well informed about the brand they are already attached with (Tawney, 2017). Advertisements against Islam's teachings and Islam's religious values and belief systems can offend Muslim consumers (Abbasi, Akhter, \& Umar, 2011).

Consumers with strong religious affiliations are less attracted to new trends and fashions. Consumers with a strong religious affiliation are well informed and less confused about the item they are buying. Religion plays a vital role in daily consumer life, and we get easily influenced by religion. We are connected and cognate to our religious values, a particular group, or the sect that can be considered religious affiliation. The consumer has certain norms and values of our culture/society one must follow in a definite pattern. It can be regarded as the guideline to spend a life. Human beings are emotionally and convivially connected to ALLAH (GOD) and divine rules and regulations. Religious affiliation of retailers can also be considered as a set of connections between retailers and religion (Ismail et al., 2019). It is perceived that religion strongly impacts a person's faith and personal life, buying patterns, and intention to consume a product/service. Religion provides instructions to follow and a guideline to deport concretely (Wan Ismail et al., 2019). Religious tradition may provide a path for a consumer to make choices in purchasing if the consumer is following the improvement of his religion. Suppose a religion does not offer guidelines cognate to buying concretely. In that case, religion can influence a consumer indirectly, for example, the buying patterns in the month of fasting, notion, and restriction cognate to clothing in faith (Bukhari et al., 2019).

Consumer buying motive (CBM) is the intention to fulfill a desire or need that makes individuals buy some item. A consumer may have many buying motives behind its intention to purchase, e.g., friends and family, emotional attachment, health and diet, age, gender, and many other motives behind its buying. The studies revealed that the youngest consumer is less concerned about organic food than the old consumer because of their health and diet issues (Abu-Alhaija et al., 2017). A motive is an inside component that stimulates, coordinates, and incorporates a man's conduct, which a craving will activate. Intentions are the beginning stage that dispatches the choice procedure (Hawlitschek, Teubner, \& Gimpel, 2018). Religiosity has been conceptualized as a complex construct. Religiosity can be known as, in terms of religiousness, a person who has strong faith and belief. It can have the synonym of piousness, devotion towards religion, and holiness. Many authors revealed that religiosity has two dimensions, intrinsic religiosity and extrinsic religiosity (Mensah \& Azila-Gbettor, 2018). Moreover, researchers and marketing experts have held religion as a critical social impact in cutting-edge purchaser practices. Religion is considered a strong social impact in the commercial areas that should be perceived and looked into an advertising perspective.

Muslim buyers' inclination to purchase items with insufficient data, and purchase new items before others, was proposed to be identified with Islamic lessons foreordained in life and studied faith and belief intensely (Mutalib et al., 2019). Religion is a necessary construct, but many controversies are attached to it. This topic is under-researched and got less attention than the 
many other research constructs. It is a construct required to consider and to work on it. The utilization of religion in retailing is frequently a wellspring of debate, be that as it may. Religiosity tends to direct the impact of consumer buying intention. In particular, shoppers with a more elevated amount of religiosity and purchasing useful items tend to have a higher buy aim. Companies are spending a lot of money creating a good image and brand awareness in customers. Companies face fierce competition, and every company tries to grasp more \& more market share. Marketers want to give the impression that they can provide every solution for consumers' problems (Shome, Jabeen, \& Rajaguru, 2018). Marketers have to put much effort into making consumers loyal and giving them an impression that the product/service they are buying is the solution to their problems.

This study aims to determine the impact of the religious affiliation of retailers (RAR) on consumers' purchase intentions (CPI) with the mediating role of CBM and moderating role of intrinsic and extrinsic religiosity. The study will address the following research questions. To what extent does the RAR have an optimistic influence on CBI? Does CBM mediate the association between the RAR and CPI? Does intrinsic religiosity moderate the connection between the consumers' buying motives and intentions? Does extrinsic religiosity moderate the association between CBM and purchasing behavior?

For this purpose, we draw on belief congruence theory (Insko, Nacoste, \& Moe, 1983). The belief congruence theory provides knowledge about similarities and dissimilarities' attitudes, values, and beliefs. As per congruence theory, it is grounded on two main pillars likeness and importance. When a consumer finds the similarity between his own and retailer's beliefs, he gets attracted to purchase from that shop. Revealed that the similarity between the retailer and consumer could lead the retailer towards the favorable condition. For example, retailers with shared birthplaces and birthdays can develop a positive relationship with consumers.

Moreover, the consumer with the same religious values as the retailer will prefer that retailer whenever the consumer intends to purchase. The main thing for retail is to examine the belief congruence because a customer may compromise on the other characters. However, religion will be the dominant characteristic in consumers' life choices. The consumer prefers his religious values (Baillargeon, Buttelmann, \& Southgate, 2018).

\section{Literature Review}

Tiffany (2019) stated that religious afflation could lead to purchasing or boycotting goods/services. Religion is an essential part of human life. The Muslim world's religious Affiliation can substantially impact the consumer indented to buy something. Throughout the previous three decades, extensive research has built a connection between social and subcultural qualities and parts of buyer conduct. Be that as it may, religion as intrinsic human esteem has gotten little consideration from consumers researching this direction. Zelin et al. (2019) specified that religion is a global phenomenon. Every marketer should understand that it is not the only concern of local business, but businesses around the globe should be concerned about the importance of religion. Understanding the social value and religious values of the immigrant moving towards the other country is genuinely paramount for the host country. They will have to adopt worldwide ethical strategies to grasp the consumers.

Nickerson and Nandialath (2019) elaborated that religious Affiliation can be the secret to hold consumers worldwide. Each consumer originates from a different culture with its way of life and its particular piece of moral esteems. Religious comprehension can lead advertisers to comprehend these distinctions and serve in a better way. Religious Affiliation of retailer can lead a consumer towards the purchase intention. Researchers have concentrated on religious Affiliation and religious commitment so profoundly to comprehend its impact in the market. The 
consumer is more worried about the religiously permitted or denied items. Usually prefer to purchase from religiously legitimate retailer (Rauf, Prasad, \& Ahmed, 2019).T. Islam and Chandrasekaran (2019) stated that consumer who is strongly affiliated to religion and give importance to cultural norms and values show higher life satisfaction as compared to those who are not affiliated to religious, such people show a lower level of life satisfaction. A consumer may consume the product to show its affiliation with religion; sometimes, the consumer purchases the product to intend to buy it just because of the religious interference in his life. The consumer tries to correlate itself with religion. That is why religion is essential in consumer daily life decisions and buying of an item. Purchasing is a part of the daily life routine where religion influences. If a person is religiously affiliated, he may go for the product; his religion allows him to buy (Shome et al., 2018).

H1: Religious affiliation of retailers has a significant positive impact on consumer purchase intention.

Wahab et al. (2018) explained that pleasure could be the buying motive to buy anything consumers liked. The researcher said in their studies that pleasure is an essential factor in buying. Consumer buying motive explained to a consumer why he is buying that specific article from a retailer. Sometimes consumer purchases an item just for the sake of pleasure without considering the other factors. Korry and Suartini (2019) revealed that consumers sometimes buy because of hedonic buying motives, such as adventure, pleasure, etc. The ultimate goal of these motives can be the enjoyment of consumers, consumer fantasies, and fun. Another consumer buying motive can be known as uniqueness. Such type of consumers buys to feel different and out of this world. Wisnalmawati (2018) uncovered that consumer buying motives could manage a buyer to consider an article that will, at last, lead him towards the consumer purchase intention. Marketing researchers have suggested that the value inspires the consumer to participate in retail shopping to fulfill their desires and necessities. Consumer loyalty or repetitive buying is essential for the survival and achievement of any store. By concentrating on stores, researchers find out the repetitive buying of experienced purchasers. An organization with high performance and a superior environment will positively influence the consumer's purchase intention because a consumer will have loyalty towards the organization, and he will be motivated to buy from the specific retailer. Consumers' needs will be satisfied by purchasing from that retailer (Wijaya \& Ardyan, 2018).

Singh (2018) define the utilization of halal-marked nourishments as an essential qualifying condition for creating, keeping up, and fortifying a general Islamic way of life and personality and is an instrument for soothing soundness. Consumer buying motives are generally moderately stable qualities that develop in individuals' lives, direct conduct through states of mind, perception, and motives, which may effectively change after some time and place. Consumer buying motives can behave like drivers for a consumer who can lead them toward the retailer. Consumer buying motives can act as a path or direction for consumers in their purchasing process (Dey \& Srivastava, 2017). Based on previous studies by J. U. Islam, Rahman, and Hollebeek (2018), the influence of the social system on the consumer, for example, cultural norms and values. The second category is the situational influence; for example, the consumer's current situation; time can be the main factor and the physical condition of the consumer. The third category is consumer psychology and its influences on consumer buying. The fourth and final category is the influence of the marketing mix on the consumer, for example, price, place, etc. Kwahk and Kim (2017) contend that consumer buying motive is the most crucial indicator of the rehash buy goal. There are significant shopping objectives. The retailer and consumers need to examine consumer groups sharing similar consumption patterns. The connecting point between the consumers with each other and with the retailer. Consumer buying motives will have a positive influence on purchase intentions. 
H2: Consumer buying motive mediates the relationship between the religious affiliation of retailers and consumer purchase intention.

Religiosity divide into two main pillars one is intrinsic, and the second is extrinsic religiosity. A consumer with higher intrinsic religiosity would be more persuaded to coordinate religion in their lives since religion will be their priority, so they will mean to purchase from a retailer with similar religious values (Nurhayati \& Hendar, 2019). Researchers revealed that customers with intrinsic religiosity would be more convenient with less knowledge about the article. These purchasers will dependably go for discounts, negotiating while purchasing. These buyers are less inventive, and forthcoming new trends inspire them. These consumers are less demanding than extrinsically religious consumers (Mendolia, Paloyo, \& Walker, 2019). Religion cannot be ignored because it is a vital factor in marketing. Religion can be an essential inspiration for buyers in their acquiring decisions. They will buy upon their prior religious beliefs.

Religiosity acts as a moderator, and it directs the connection between consumer buying motives and consumer purchase intention. Muslims follows their religion Islam in their day-by-day life. Islam gave them an appropriate rule on how to carry, on the most proficient method to live and trade. For example, eating pork and drinking liquor is entirely disallowed in Islam, so Muslim customers completely take care of this convention. They eat kosher meat concurring the educating of their religion. Muslim Consumers are delicate about their religious values. Muslims in Malaysia who comprehend the teaching of religion give importance to it. Do they take care of what to purchase? Also, the amount we ought to purchase is indicated by the instruction of Islam (Allen et al., 2019). de Campos et al. (2019) elucidated that religiosity plays a vital role in the formation of consumers' attitudes, and it has a significant relationship with the question of why people purchase or intend to purchase. Individuals' different beliefs and values lead him towards different perceptions. That guides him to select the additional solution of his problems so the better understanding of religion will lead the retailer to understand consumer buying behavior in a better way. It will result in more efficient strategies and policies related to the consumer.

H3: Intrinsic religiosity moderates the relationship between consumer buying motives and intentions.

Moreover, extrinsically religious consumers will specifically follow the teachings of their religion, which will be more appropriate for them as indicated by the circumstance. So, they receive faith in business and daily life as per the environment (Ansar, Mahdi, \& Susi, 2019). On the contrary, the extrinsically religious shopper will have information about the article and the importance of item quality. They are more liberal as a contrast with the intrinsically religious consumer. Extrinsically religious buyers are more creative and consider new patterns and forms while buying. They expect to purchase an item of higher quality. The great or horrible manner of shoppers towards a nation brings about acknowledgment or dismissal of items or administrations offered by that nation (Bauer \& Johnson, 2019). Customers may have a sentiment antagonistic vibe or hostility towards certain countries, boycotting their items and administrations. Religion serves as a solid intention in shopper buy conduct, and their goal to act as a stable connection had found amongst religion and nourishment decision utilization among shoppers (Iqbal \& Iqbal, 2019).

H4: Extrinsic religiosity moderates the relationship between consumer buying motives and intentions.

Next section reports the research methodology and data sampling technique with geographical representation. The subsequent sections represent data analysis and discussion of results, and summary of results and conclusion, respectively. 


\section{Research Sample and Methods}

The study's design was based on both quantitative practices in applied and descriptive in the theoretical part with non-experimental and cross-sectional nature. This study used an analytical approach and experiential research to examine the correlation in practices. Therefore, for data collection, a survey was conducted to regulate the impact of the religious affiliation of retailers on consumer purchase intention with mediating role of consumer buying motives and moderating role of intrinsic and extrinsic religiosity. For this purpose, the data were collected from the different cities of Pakistan. Among a total of 960 questionnaires distributed to the respondents, 510 questionnaires were selected based on the completeness of the responses. Most importantly, these demographic zones were chosen based on population density. Figure 1 below shows the ArcMap of the sampling zones of this study.

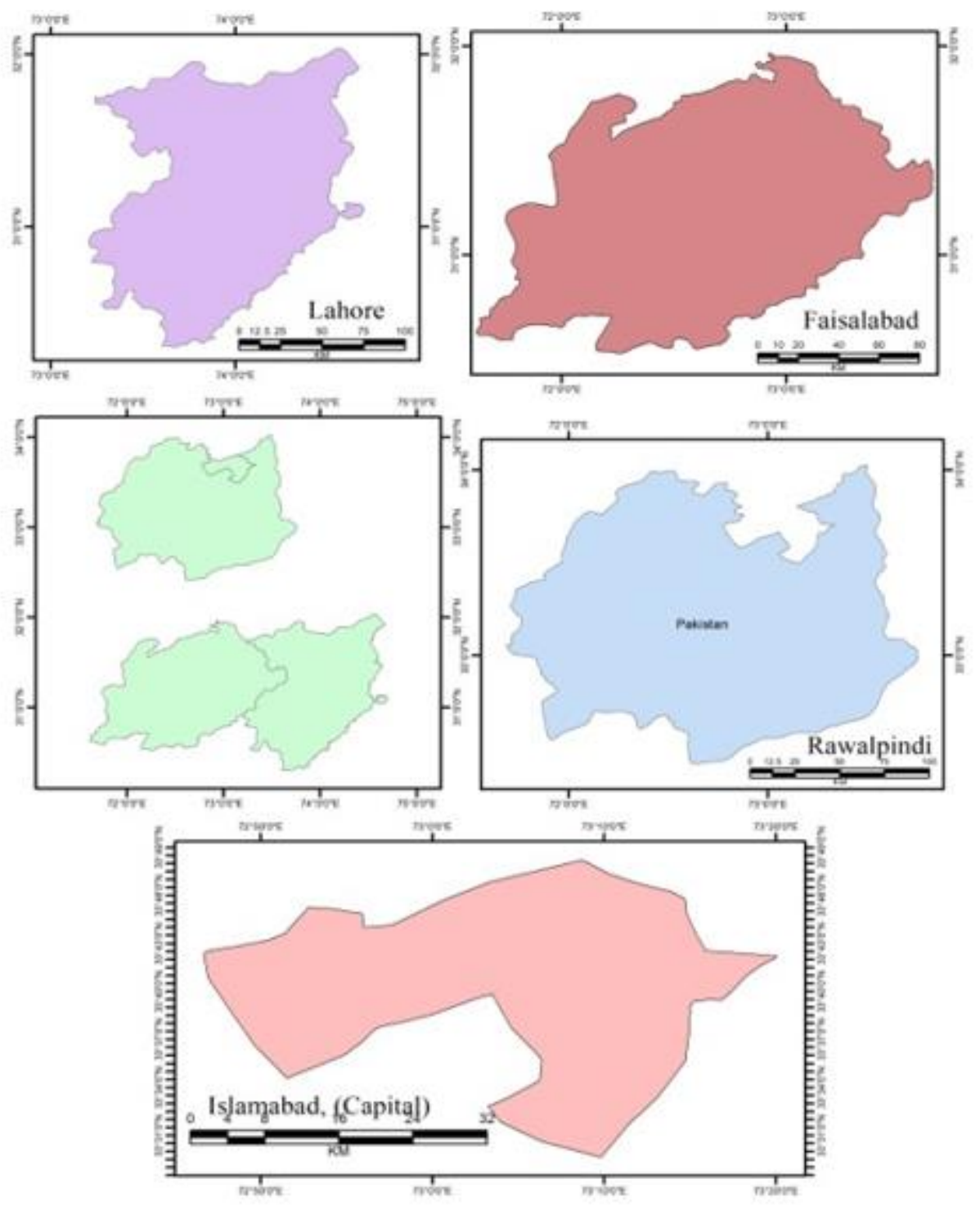

Figure 1: The ArcMap of the sampling zones of this study

\section{Research Framework and Instruments}

Figure 2 shows the research framework. The study uses the religious affiliation of retailers (RAR) as an independent variable, consumer purchase intention (CPI) as a dependent variable, consumer buying motives (CBM) as mediating variables, and religiosity (Intrinsic and extrinsic religiosity) as moderating variable. 


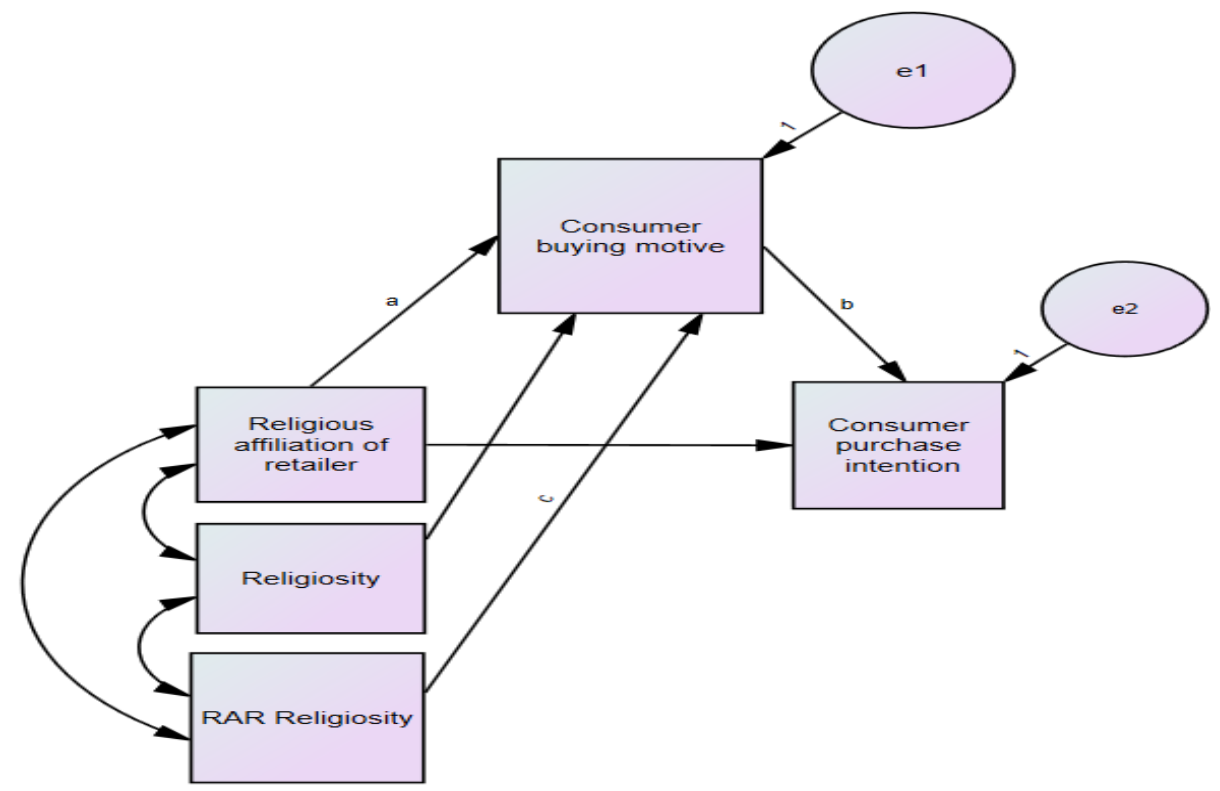

Figure 2. Moderated Mediation Research Model

\section{Data Analysis}

To examine the data, different statistical and mathematical tools are used in this study to measure the relationship. Correlation is used to determine the extent to which RAR influences CPI. In contrast, Regression is used to inspect how much variation in the independent variable instigated the dependent variable. The demographic factors including Age and Gender are used in this study.

The study used statistical packages SPSS-V.22, AMOS, MS-Excel, and ArcMap.

Table 1 presents the sources of study instruments and their corresponding reliability using Cronbach Alpha.

Table 1. Measurement of Variables and Reliability Test

\begin{tabular}{llll}
\hline Variables & Authors & Proxies/Items & Reliability \\
\hline RAR & (Siala, O'Keefe, \& Hone, 2004) & 08 & 0.731 \\
CPI & (Chaisurivirat, 2009) & 03 & 0.789 \\
CBM & (Huda \& Sultan, 2013) & 07 & 0.792 \\
R & (Alhouti, Musgrove, Butler, \& D'Souza, 2015) & 08 & 0.821 \\
\hline
\end{tabular}

Figure 3 below represents the demographic characteristics of respondents showing that the sample consists of $64 \%$ men and $36 \%$ women. The highest response rate was $33.9215 \%$ respondent group comprised of 26 - 33 years of age, and the lowest age group responded $4.5 \%$ who were 50 - 60 years of age. The other demographic factor is the qualification which is also considered in this study to target the sample size. 


\section{DEMOGRAPHIC PHYSIOGNOMIES OF RESPONDENTS}

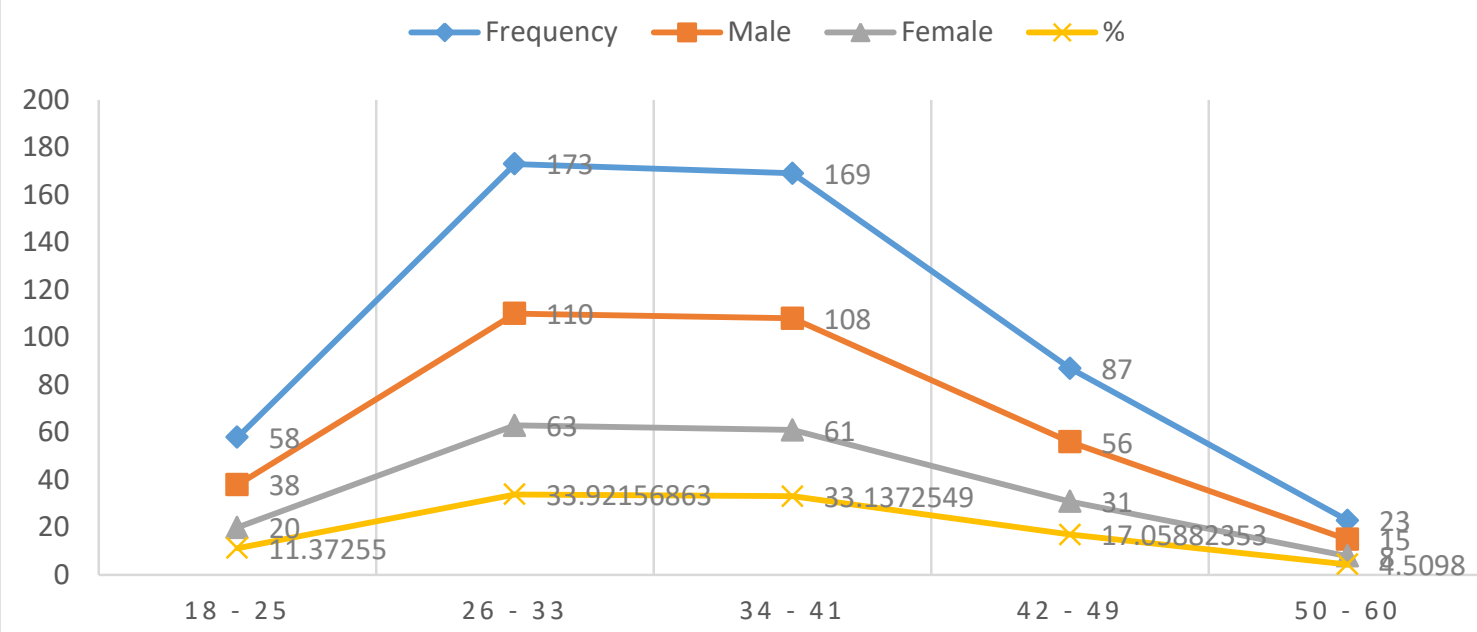

AGE

Figure 3. Age and Gender Demographics

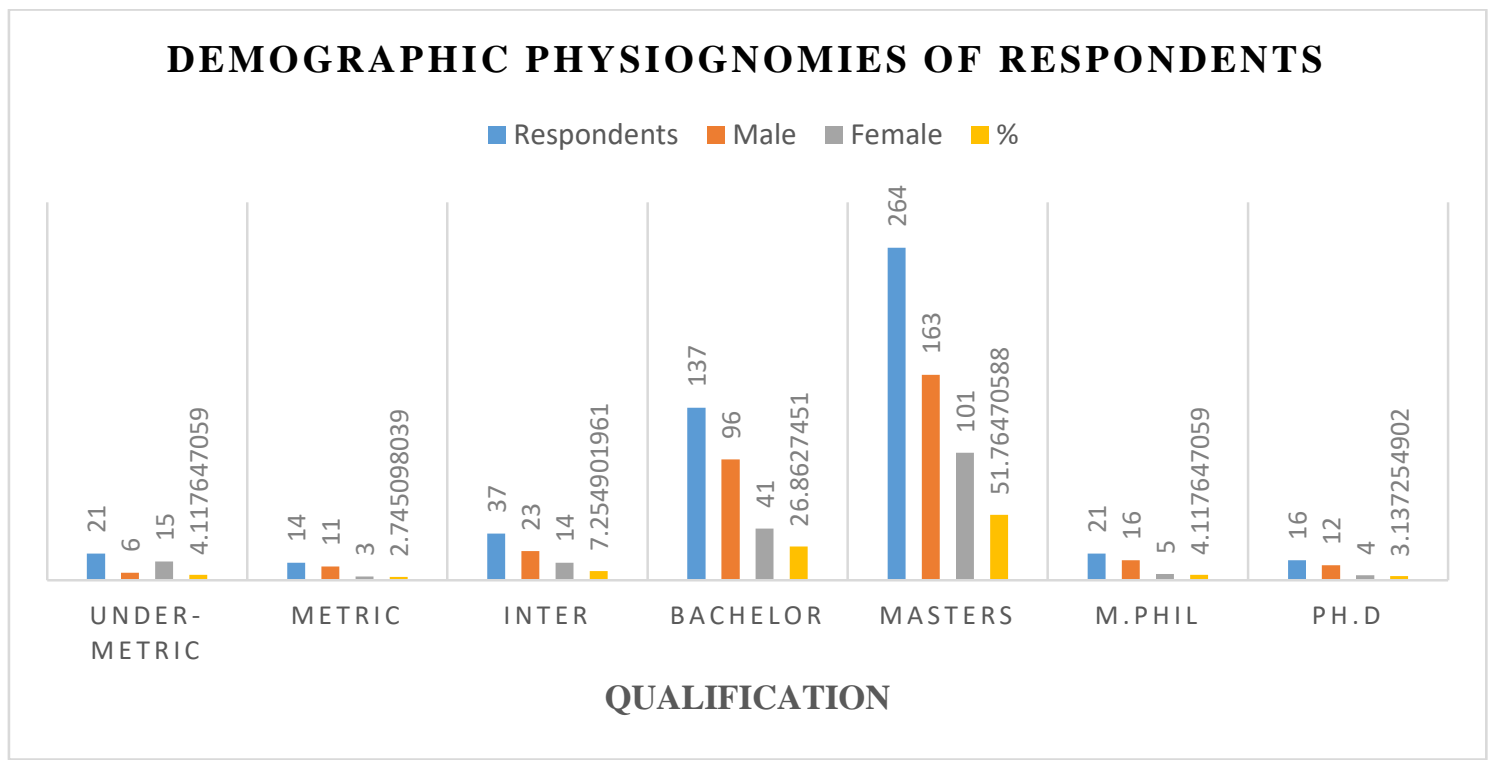

Figure 4. Qualification Demographics

Figure 4 shows the qualification of the selected sample size, which indicates that most of the respondents have higher education. Results also reveal that $52 \%$ of the respondent have Master's degrees out of the total sample size, in which $27 \%$ of respondents have Bachelor's degrees. Rest, $7 \%$ of the respondents have Doctorate degrees (which comes under M.Phil. and Ph.D. categories).

Table 3. Descriptive Analysis

\begin{tabular}{llllll}
\hline & Sample & Minimum & Maximum & Mean & St. Div. \\
\hline Gender & 510 & 1.0 & 2 & 1.26 & 0.440 \\
Age & 510 & 1.0 & 5 & 2.83 & 1.235 \\
Qualification & 510 & 1.0 & 7 & 3.78 & 1.387 \\
Religious Affiliation of Retailers & 510 & 1.0 & 4.433 & 3.58 & 0.748 \\
Consumer Buying Motives & 510 & 1.0 & 4.712 & 3.40 & 0.825 \\
Consumer Purchase Intention & 510 & 1.0 & 4.333 & 3.25 & 1.048 \\
Intrinsic Religiosity & 510 & 1.0 & 4.758 & 3.80 & 1.018 \\
Extrinsic Religiosity & 510 & 1.0 & 5.000 & 2.914 & 1.169 \\
\hline
\end{tabular}


Descriptive analysis of data (Table 3) shows that the study contains a total population size of 510, with the maximum number of respondents of males with a Master's degree education. The mean value for religious affiliation of retailer (RAR) is 3.58 with a St. Deviation of 0.748 . It means that the eight proxies used to measure the RAR show a positive and significant relationship. RAR has reported that they sell products with religious traditions and beliefs. This study also found that if religious retailers have stock from non-religiously conforming items while the market has religious items, then the consumer avoids purchasing from that particular retailer. Results confirmed that most retailers shop from places where the beliefs are the same and sell to individuals who do not have the same religion.

The mean value of consumer buying motive (CBM) is 3.40 with a standard deviation of 0.825 , which means that seven proxies of CBM also show a positive and significant trend. In this study, the survey concludes that consumers are the most concerned with religious items, and they believe that those products are better for their health and life. The study also reveals that consumers are also influenced by their families and friends due to the old and robust beliefs, leading them to another trustworthy thought and commitment to the product's originality.

Furthermore, the mean value of consumer purchase intention (CPI) is 3.25 with a St. Deviation of 1.048, which states that all CPI proxies have a positive and significant trend. The result shows the significant trend between consumer loyalty and religious retailer commitment. This study also checks the impact of old family's commitment and retailer religiously commitment and results found a significant relationship with each other.

However, religiosity investigates through two different aspects, intrinsic religiosity, and extrinsic religiosity, and both are measured through 03 and 04 other proxies. The mean value of intrinsic religiosity is 3.80 and the St. Deviation of 1.018, which shows the positive bonding between religiosity and buy and selling patterns. Statistics report that religious affiliations between retailers and consumers made their bounding secure and productive due to their beliefs. The more religious retailers are, the more religious consumer they have. Furthermore, the mean value of extrinsic religiosity is 2.914 with a St. Deviation of 1.169 , showing a positive and significant trend. Extrinsic religiosity has the lowest mean value, 2.914, with the highest standard deviation of 1.169. Religion is a more important factor for consumers and retailers as extrinsic and intrinsic religiosity is working parallel with each other.

Table 4. Correlation Matrix

\begin{tabular}{|c|c|c|c|c|c|c|c|c|}
\hline & CPI & Gender & Age & QUA & RAR & CBM & IR & $\mathrm{ER}$ \\
\hline Consumer Purchase Intention & 1 & & & & & & & \\
\hline Gender & -.053 & 1 & & & & & & \\
\hline Age & -.072 & -.028 & 1 & & & & & \\
\hline Qualification & -.109 & .057 & -.047 & 1 & & & & \\
\hline Religious Affiliation of Retailer & $.506 * *$ & -.038 & .038 & -.159 & 1 & & & \\
\hline Consumer buying motive & $.610 * *$ & .115 & .030 & -.083 & $.699 * *$ & 1 & & \\
\hline Intrinsic religiosity & $.402 * *$ & .042 & .000 & -.098 & $.561 * *$ & $.412 * *$ & 1 & \\
\hline Extrinsic religiosity & -.098 & -.125 & -.083 & .117 & $-.174 *$ & $-.155^{*}$ & $-.196 * *$ & 1 \\
\hline
\end{tabular}

Table 4 reports that the correlation matrix, in which the first demographic variable (Gender) shows an insignificant relation with CPI. It has no impact on CPI. Matrix also reported that the 2nd demographic variable, age, has no significant correlation with consumer purchase intention. The last demographic variable qualification is also showing insignificantly correlated with CPI. However, RAR is significantly associated with CPI, where $\mathrm{r}$ value 0.506 , where $\mathrm{p}<0.01$. Table 4 shows the significant relationship of the mediator consumer buying motive (CBM) with CPI, 
where the $\mathrm{r}$ value is 0.610 and $\mathrm{p}<0.01$. This table also indicates the significant and positive correlation of moderator (Intrinsic religiosity), and the $r$ values are 0.402 and $p<0.05$. The other moderator (extrinsic religiosity is insignificantly correlated with CPI, where the importance of $r$ is -0.9 .

By following the bootstrapping method, the mediation analysis results indicate the full direct and indirect effects of Mediation analysis (Hair, Hult, Ringle, Sarstedt, \& Thiele, 2017; Preacher \& Hayes, 2008). It contained 95\% confidence intervals (CI) and 5000 bootstrap re-samples used for analysis.

Table 5. Regression Analysis for Mediation between RAR and CPI (Mediator CBM)

\begin{tabular}{lllll}
\hline & Effect Size & S.E & LL 95\% CI & UL 95\% CI \\
\hline Total-Effect & 0.8771 & 0.0786 & 0.7220 & 1.028 \\
Direct-Effect & 0.5722 & 0.1034 & 0.3238 & 0.7315 \\
Indirect-Effect & 0.3478 & 0.0721 & 0.2141 & 0.4996 \\
\hline
\end{tabular}

S.E $=$ Standard error, $\mathrm{LL}=$ Lower limit, $\mathrm{UL}=$ Upper limit, $\mathrm{CI}=95 \%$ Confidence interval

Table 5 shows the total effect, which indicates the relationship between the retailer's religious affiliation and consumer purchase intention, which turned out to be 0.8771 with LL 0.7220 and UL 1.028. It shows the strongly significant and positive relationship between RAR with CPI. The direct effect shows the impact RAR pooled with CBM on CPI. The immediate impact is 0.5722 with LL 0.3238 and UL 0.7315 . The mediation is led by the indirect effect, which turned out to be 0.3478 with LL 0.2141 and UL 0.4996 . Results have shown that religious affiliation retailer is positively associated CPI and CBM mediate the relationship between RAR and CPI. These results lead to the acceptance of $\mathrm{H} 1$ and $\mathrm{H} 2$.

Table 6. Regression Analysis for Moderation between CBM and CPI (Moderation IR \& ER)

\begin{tabular}{llllll}
\hline Variable & B & S.E & Prob. & LL 95\% CI & UL 95\% CI \\
\hline Int_1(CBM*IR) & 0.1390 & 0.0660 & 0.0364 & 0.0089 & 0.2691 \\
Int_2 (CBM*ER) & -.0461 & 0.0648 & .4778 & -.1740 & 0.0817 \\
\hline
\end{tabular}

Table 6 shows that the $\beta$ value for intrinsic religiosity is 0.1390 . Intrinsic religiosity has a significant moderating role with a p-value of 0.03 below 0.05 . The non-zero value exists between the upper and lower limits. Intrinsic religiosity had a moderating role between consumer buying motive and consumer purchase intention with LLCI (0.0089) and ULCI (0.2691). These values lead to the acceptance of $\mathrm{H} 3$ that intrinsic religiosity moderates the relationship between consumer buying motives and consumer purchase intention. However, extrinsic religiosity $\beta$ value -.0461 and the LLCI (-.1740) and ULCI (0.0817). Extrinsic religiosity shows an insignificant relationship with a p-value of 0.4778 , higher than 0.05 presence of zero value lied among the upper limit and lower boot limits lead us towards the rejection of H4. Results from table 6 indicate that extrinsic religiosity had an insignificant relationship with consumer purchase intention. It does not mediate between consumer buying motive and consumer purchase intention. These results lead to the rejection of $\mathrm{H} 4$.

Table 7. Regression Analysis for Moderation between CBM and CPI

\begin{tabular}{llllll}
\hline Variable & $\mathrm{R}$ & $\mathrm{R}^{2}$ & $\mathrm{R}^{2}$ Change & $\mathrm{F}$ & Sig \\
\hline Intrinsic religiosity & .6604 & .4326 & 0.0414 & 3.9271 & 0.0264 \\
Extrinsic religiosity & .6212 & .3859 & 0.021 & 0.6893 & .4778 \\
\hline
\end{tabular}

Table 7 shows the intrinsic and extrinsic religiosity moderation relationship. In table showed that the value of R2 Change is 0.0414 for intrinsic religiosity and the significance value 0.0264 , which is below 0.05, shows that the relationship is significant. These values lead to the acceptance of $\mathrm{H} 3$ that intrinsic religiosity moderates the relationship between consumer buying 
motives and consumer purchase intention. Table 7 also shows that extrinsic religiosity has an insignificant relationship as the p-value is 0.4778 , which indicates that extrinsic religiosity has a minor relationship with consumer purchase intention. These results lead to the rejection of H4 that extrinsic religiosity moderates the relationship between consumer buying motives and consumer purchase intention. These results show to the acceptance of $\mathrm{H} 3$ and rejection of $\mathrm{H} 4$ that intrinsic and extrinsic religiosity moderates the relationship between consumer buying motives and consumer purchase intention.

\section{Results and Discussion}

As the results show that RAR has a strong influence on CPI, H1 is accepted, which assumes that the religious affiliation of the consumer has a significantly positive impact on consumer purchase intention. Results indicate that the religious affiliation of consumers showed a positive association with CPI. The consumer will be attracted towards the product/service aligned with his religious values. The consumer may buy the thing to demonstrate its alliance with religion; once in a while shopper buy the item or intend to buy the item due to the religious affiliation in his life. The consumer tries to associate itself with religion (Lindridge, 2005).

The study indicates that consumer buying motives mediate the relationship that leads towards the acceptance of H2. Consumer buying motive is also an important construct, and results showed that it has a strong mediation role. Consumer buying motives mediate the connection between the religious affiliation of consumers and consumer purchase intention. The purchaser buys an article based on his preferences, and customer inclinations give direction to choose, aim to purchase. The purchaser accepts these items to satisfy his needs and goals. This buying process includes mental, passionate, and physical exercises (Zanoli \& Naspetti, 2002). This study reveals that consumers consider factors like quality, friend, and family environment while purchasing an article.

The study indicates that intrinsic religiosity also has a significant moderating relationship with consumer buying motives and consumer purchase intention. Consumer religiosity has two dimensions, intrinsic religiosity (IR) and extrinsic religiosity (ER). This develops the consumer guideline that moderates the relationship between CBM and CPI. According to the study results, intrinsic religiosity is the inner religious motivation, and it is stronger. It moderates the relationship between consumer buying motive and consumer purchase intention. Shoppers with higher intrinsic religiosity will be more induced to put religion in their life since religion will be their first need, so they will intend to buy from a retailer with comparative religious values (Allport \& Ross, 1967; Emmons \& Paloutzian, 2003; Hill \& Pargament, 2008). As per the results, H4 is rejected, so extrinsic religiosity is insignificantly related to consumer purchase intentions. Extrinsic religiosity is the religious motivation from outside form the environment. Extrinsically religion-oriented shoppers will mainly take care of their religious values, which will be more suitable for them, as shown by the condition.

The result shows that the three hypotheses $(\mathrm{H} 1, \mathrm{H} 2, \mathrm{H} 3)$ are accepted. There is a significant favorable influence of religious affiliation of the consumer on CPI with mediating role of CBM and moderating role of intrinsic religiosity. In contrast, the fourth hypothesis is rejected that extrinsic religiosity moderates the association between CBM and CPI.

\section{Conclusion}

The study determined to find the impact of RAR on CPI with the mediating role of CBM and moderating role of IR and ER. This study chose the sample size from the Capital City of Pakistan and three other cities from Punjab Province. Observing and studying the trend and pattern from 510 respondents using different statistical tools mentioned in the research methodology. This study shows that RAR has a significant and positive impact on CPI as RAR substantially 
influences consumer decisions. Consumers are concerned with the product originality, religious beliefs, and a strong family bonding with religious retailers; they have a strong intention to buy the products. Religion is the main element of the consumer decision-making process, which is the foremost factor in consumer buying motives. Religious affiliation of retailers (RAR) has a determinable effect on consumer purchase intention (CPI).

This study has explicitly focused on the religious affiliation of the retailer and its impact on consumer purchase intention in which CBM mediate the relationship, as consumers consider the traditional and strong belief of religion, which also make them loyal customers to the niche segment. Study shows that intrinsic religiosity moderates the relationship between consumer buying motive and intention. This moderate religiosity factor stated that the inner consumer belief matters a lot and directly relates to CBM and CPI. If the consumer has an intense intrinsic religiosity, they have a clear moto behind buying from the religiosity retailers and vice versa. This study also reveals that if a consumer has an inherent religiosity, there will be a significant relationship between RAR and CPI and vice versa.

Moreover, the study reveals that extrinsic religiosity does not moderate the relationship between $\mathrm{CBM}$ and CPI. Materialistic-minded consumer beliefs that religion can be molded according to the situation. Therefore, they do not have a strong faith and bonding with religious factors, as this study reveals that extrinsically religious people do not take religion as their priority.

The consumer is the backbone for every business, so it is becoming necessary to consider the factors that affect consumers in their purchasing process as most people are Muslims. By this, the retailer can make better policies to attract the consumer. A retailer can use this study to create strategies for a business retailer to consider religion essential in daily consumer life. A developing country needs to give importance to the business to boost the economy.

\section{References}

Abbasi, A. S., Akhter, W., \& Umar, S. (2011). Ethical issues in advertising in Pakistan: an Islamic perspective. World Applied Sciences Journal, 13(3), 444-452.

Abu-Alhaija, A., Yusof, R., Hashim, H., \& Jaharuddin, N. (2017). The motivational approach of religion: the significance of religious orientation on customer behaviour. International Journal of Economics, Commerce and Management, 12, 609-619.

Alhouti, S., Musgrove, C. F., Butler, T. D., \& D’Souza, G. (2015). Consumer reactions to retailer's religious affiliation: roles of belief congruence, religiosity, and cue strength.

Journal of Marketing Theory and Practice, 23(1), 75-93. https://doi.org/10.1080/10696679.2015.980176

Allen, K., Arbeeva, L., Campbell, L., Cené, C., Keefe, F., Oddone, E., . . Coffman, C. (2019). Identifying subgroups of African American patients with differential improvement following a pain coping skills training program for osteoarthritis. Osteoarthritis and Cartilage, 27, S489. https://doi.org/10.1016/j.joca.2019.02.543

Allport, G. W., \& Ross, J. M. (1967). Personal religious orientation and prejudice. Journal of personality and social psychology, 5(4), 432-443. https://psycnet.apa.org/doi/10.1037/h0021212

Ansar, R., Mahdi, S. A., \& Susi, W. (2019). The relationship of money ethics on tax evasion with intrinsic religiosity, extrinsic religiosity, and materialism as moderating variables (Case on private taxpayers listed in KPP Pratama Ternate). Jurnal Accountability, 7(02), 33-47. https://doi.org/10.32400/ja.24691.7.02.2018.33-47

Baillargeon, R., Buttelmann, D., \& Southgate, V. (2018). Invited commentary: Interpreting failed replications of early false-belief findings: Methodological and theoretical considerations. Cognitive Development, 46, 112-124. https://doi.org/10.1016/j.cogdev.2018.06.001

Barrett, J. L. (2011). Cognitive science of religion: Looking back, looking forward. Journal for the Scientific Study of Religion, 50(2), 229-239. 
https://doi.org/10.1111/j.1468-5906.2011.01564.x

Bauer, A. S., \& Johnson, T. J. (2019). Conceptual overlap of spirituality and religion: An item content analysis of several common measures. Journal of Spirituality in Mental Health, 21(1), 14-36. https://doi.org/10.1080/19349637.2018.1437004

Bukhari, S. F. H., Woodside, F. M., Hassan, R., Shaikh, A. L., Hussain, S., \& Mazhar, W. (2019). Is religiosity an important consideration in Muslim consumer behavior. Journal of Islamic Marketing, 10(4), 1288-1307. https://doi.org/10.1108/JIMA-01-2018-0006

Chaisurivirat, D. (2009). The effect of corporate social responsibility: Exploring the relationship among CSR, attitude toward the brand, purchase intention, and persuasion knowledge. Graduate Theses and Dissertations, Digital Commons, University of South Florida. https://digitalcommons.usf.edu/etd/1894

de Campos, R. J. D. S., Lucchetti, G., Lucchetti, A. L. G., da Rocha Ribeiro, T. C., Chebli, L. A., Malaguti, C., . . . Chebli, J. M. F. (2019). The Impact of Spirituality and Religiosity on Mental Health and Quality of Life of Patients with Active Crohn's Disease. Journal of religion and health, 1-14. https://doi.org/10.1007/s10943-019-00801-1

Dey, D. K., \& Srivastava, A. (2017). Impulse buying intentions of young consumers from a hedonic shopping perspective. Journal of Indian Business Research, 9(4), 266-282. https://doi.org/10.1108/JIBR-02-2017-0018

Emmons, R. A., \& Paloutzian, R. F. (2003). The psychology of religion. Annual review of psychology, 54(1), 377-402. https://doi.org/10.1146/annurev.psych.54.101601.145024

Hair, J. F., Hult, G. T. M., Ringle, C. M., Sarstedt, M., \& Thiele, K. O. (2017). Mirror, mirror on the wall: a comparative evaluation of composite-based structural equation modeling methods. Journal of the Academy of Marketing Science, 45(5), 616-632.

https://doi.org/10.1007/s11747-017-0517-X

Hawlitschek, F., Teubner, T., \& Gimpel, H. (2018). Consumer motives for peer-to-peer sharing. Journal of Cleaner Production, 204, 144-157. https://doi.org/10.1016/j.jclepro.2018.08.326

Hill, P. C., \& Pargament, K. I. (2003). Advances in the conceptualization and measurement of religion and spirituality: Implications for physical and mental health research. American Psychologist, 58(1), 64-74. https://doi.org/10.1037/0003-066X.58.1.64

Huda, M. M., \& Sultan, P. (2013). Buying motives of herbal skin care products: The case of generation Y in Bangladesh. International Review of Business Research Papers, 9(5), 6880.

Insko, C. A., Nacoste, R. W., \& Moe, J. L. (1983). Belief congruence and racial discrimination: Review of the evidence and critical evaluation. European Journal of Social Psychology, 13(2), 153-174. https://doi.org/10.1002/ejsp.2420130206

Iqbal, N., \& Iqbal, S. (2019). English-impact of islamic religiosity, islamic associations, biased behaviors and working capital management: Evidence from OIC countries. The ScholarIslamic Academic Research Journal, 5(1), 129-145. https://doi.org/10.29370/siarj/issue8ar14

Islam, J. U., Rahman, Z., \& Hollebeek, L. D. (2018). Consumer engagement in online brand communities: a solicitation of congruity theory. Internet Research, 28(1), 23-45. https://doi.org/10.1108/IntR-09-2016-0279

Islam, T., \& Chandrasekaran, U. (2019). Religiosity, values and consumer behaviour: a study of young Indian Muslim consumers. Journal of Consumer Marketing, 36(7), 948-961. https://doi.org/10.1108/JCM-10-2017-2415

Korry, P. D. P., \& Suartini, N. W. (2019). Hedonism and culture toward impact of shopping behavior. International journal of social sciences and humanities, 3(1), 125-133. https://10.29332/ijssh.v3n1.260

Kwahk, K.-Y., \& Kim, B. (2017). Effects of social media on consumers' purchase decisions: evidence from Taobao. Service Business, 11(4), 803-829.

https://doi.org/10.1007/s11628-016-0331-4 
Lindridge, A. (2005). Religiosity and the construction of a cultural-consumption identity. Journal of Consumer Marketing, 22(3), 142-151. https://doi.org/10.1108/07363760510595968

Mendolia, S., Paloyo, A., \& Walker, I. (2019). Intrinsic Religiosity, Personality Traits, and Adolescent Risky Behaviors. The BE Journal of Economic Analysis \& Policy, 19(3), 20180311. https://doi.org/10.1515/bejeap-2018-0311

Mensah, C., \& Azila-Gbettor, E. M. (2018). Religiosity and students' examination cheating: evidence from Ghana. International Journal of Educational Management, 32(6), 11561172. https://doi.org/10.1108/IJEM-07-2017-0165

Mutalib, M. M. A., Sulaiman, M., Ramly, R., Othman, K., \& Ahmad, Y. (2019). Reconstruction of Religious Pluralism or Muhibah Value? A Comparative Study in Malaysia. Jurnal Sains Insani, 4(2), 49-56. https://doi.org/10.33102/jsi2019.4.2.06

Nickerson, C., \& Nandialath, A. M. (2019). The impact of religious salience on purchase intentions: evidence from the UAE. Journal of Islamic Marketing, 11(6), 1339-1350. https://doi.org/10.1108/JIMA-01-2019-0005

Nurhayati, T., \& Hendar, H. (2019). Personal intrinsic religiosity and product knowledge on halal product purchase intention: Role of halal product awareness. Journal of Islamic Marketing, 11(3), 603-620. https://doi.org/10.1108/JIMA-11-2018-0220

Preacher, K. J., \& Hayes, A. F. (2008). Assessing mediation in communication research: In. The Sage sourcebook of advanced data analysis methods for communication research. Sage Publishers.

Rauf, A. A., Prasad, A., \& Ahmed, A. (2019). How does religion discipline the consumer subject? Negotiating the paradoxical tension between consumer desire and the social order. Journal of Marketing Management, 35(5-6), 491-513. https://doi.org/10.1080/0267257X.2018.1554599

Razzaq, Z., Razzaq, A., Yousaf, S., \& Hong, Z. (2018). The Impact of Utilitarian and Hedonistic Shopping Values on Sustainable Fashion Consumption: The Moderating Role of Religiosity. Global Business Review, 19(5), 1224-1239. https://doi.org/10.1177\%2F0972150918777947

Shome, A., Jabeen, F., \& Rajaguru, R. (2018). What drives consumer choice of Islamic banking services in the United Arab Emirates? International Journal of Islamic and Middle Eastern Finance and Management, 11(1), 79-95. https://doi.org/10.1108/IMEFM-03-2017-0066

Siala, H., O'Keefe, R. M., \& Hone, K. S. (2004). The impact of religious affiliation on trust in the context of electronic commerce. Interacting with computers, 16(1), 7-27. https://doi.org/10.1016/j.intcom.2003.11.002

Singh, D. P. (2018). Integration of materialism with shopping motivations: motivations based profile of Indian mall shoppers. Journal of Asia Business Studies, 12(4), 381-401. https://doi.org/10.1108/JABS-05-2016-0075

Tawney, R. H. (2017). Religion and the Rise of Capitalism: Routledge.

Tiffany, A. R. (2019). Pedagogies and Practice: How Religious Diversification Impacts Seminaries and Clergy. University of Cambridge.

Wahab, Z., Shihab, M. S., Hanafi, A., \& Mavilinda, H. F. (2018). The influence of online shopping motivation and product browsing toward impulsive buying of fashion products on a social commerce. Jurnal Manajemen Motivasi, 14(1), 32-40.

Wan Ismail, W. R., Othman, M., Abdul Rahman, R., Kamarulzaman, N. H., \& Ab Rahman, S. B. (2019). "Is sharing really caring?" The impact of eWoM on halal tolerance among Malay Muslim consumers. Journal of Islamic Marketing, 10(2), 394-409. https://doi.org/10.1108/JIMA-04-2016-0035

Wijaya, O. Y. A., \& Ardyan, E. (2018). The Influencing Factors of Impulsive Buying Behaviour in Transmart Carrefour Sidoarjo. Binus Business Review, 9(3), 199-205. https://doi.org/10.21512/bbr.v9i3.4729

Wisnalmawati, W. (2018). The Influence Of In-Store As A Mediation To Impulse Buying (Study 
On The Retails In Yogyakarta). The 2nd International Conference on Technology, Education, and Social Science (The 2nd ICTESS 2018). bu wisnal.pdf (upnyk.ac.id)

Zanoli, R., \& Naspetti, S. (2002). Consumer motivations in the purchase of organic food: a means-end approach. British food journal, 104(8), 643-653. https://doi.org/10.1108/00070700210425930

Zelin, N. S., Solotke, M. T., Scott, C. E., Atienza-Carbonell, B., Fogas, C., Skrzypczak, J., . . . Pelzer, B. W. (2019). An Analysis of the Presence and Composition of OutLists at United States, Canadian, and European Medical Institutions. Journal of homosexuality, 1-15. https://doi.org/10.1080/00918369.2019.1621554 